Book Presentation

LAILA AL-ZWAINI

The notion of legal pluralism is known to both lawyers and social scientists. From the lawyers' point of view, it expresses the recognition by the State (the legislator) of the existence of a multiplicity of legal sources, which either constitute the official legislation, or ar admitted as subsidiary sources in case of legal lacuna. These sources can be religious law, customary law, or international treaties, amongst others. This concept thus assumes more or less ideological dimension, by whic the State wishes to accentuate its pluralistic orientation, yet does not call into question its legal monopoly.

Several socio-legal scientists have refuted this prescriptive approach to law, and reformulated the concept of legal pluralism as th parallel existence of a plurality of legal norms that are produced by different autonomous 'social fields'. These social fields possess their own normative and regulatory capacities, and are capable of enforcing these on their members. This implies that external legislation has not and cannot have the impact that it presumes to have. Studying law in this theoretical context therefore means reversing the perspective from the legislator to the social fields. In December 1996, the Centre d'Etudes et de Documentation Economique, Juridique et Sociale (CEDEJ) and the Netherlands-Flemish Institute in Cairo (NVIC) jointly sponsored a two-day round table in Cairo on the theory and practice of legal pluralism in the Arab world. The organizers of the round table (edi-

\title{
Legal Pluralism in the Arab World
}

tors of the book), wanted to develop an approach to the legal phenomenon in the Arab world which, from a sociological perspective, takes into consideration the complex of social fields adhered to by the individual, as well as the normativity and type of interaction they develop. From the different case studies that were presented, it became apparent that although the theory of legal pluralism is a handy tool for analysing socio-legal activities, there is not only 'one' such theory. Legal pluralism is a model for analysis that necessitates modification according to each specific case.

In order to grasp the subject from its multiple angles, contributors from a wide variety of disciplines and nationalities were invited: sociologists, anthropologists, political scientists, legal theoreticians, and practising lawyers originating from France, the Netherlands, Belgium, Great Britain, Germany, the United States, and Egypt. Starting with a preface by John Griffiths, whose seminal article on legal pluralism denoted the starting point of the seminar, the present publication consists of three main parts:

Part One discusses the various theories of legal pluralism (Gordon Woodman); the impossibility of sorting out norms, law, and practices (Jean-Noël Ferrié); the implications of terminology on the study of legal pluralism, as well as the need to develop an anthropology of the actors of the norms, especially in the Arab world where law is intertwined with religion (Baudouin Dupret); and a critical survey of Western law studies on Arab-Muslim countries (Jörn Thielmann).

Part Two presents case studies from a comparative perspective: a comparison between the court systems of Belgium and Egypt, especially with regard to the interpretation of norms presented as Islamic (Marie-Clair Foblets and Baudouin Dupret); a discussion of Palestinian law as a clear case of internal pluralism of state law (Bernard Botiveau); the conflict between legal pluralism and cultural unity in Morocco (Lawrence Rosen); the dissonance between Islamic law and the International Convention of the Rights of the Child (Murielle Paradelle); the shortcoming of legal pluralism to approach an emotionally-charged subject like Islamic law, as in the Syrian context (Maurits Berger); and the effects of legal pluralism in the treatment of unfair contractual terms in the United Arab Emirates and Egypt (Hassan Gemei).

Finally, Part Three deals with the phenomenon of legal pluralism in Egypt: a case of feuding families in $19^{\text {th }}$-century Egypt involving statute, and Islamic and customary law (Rudolph Peters); the working of haqa al-arab i.e. customary arbitration in Upper Egyp (Sarah Ben Nefissa); the responsibility of lega pluralism in the setback of modernity in Egyp (Nabil 'Abd al-Fattah); the enclosure of the Egyptian legal field as illustrated by the Youssef Chahine-case (Nathalie Bernard-Maugiron); the interplay of Islamic law, family law and social customs in the Egyptian Person
Status Law of 1985 (Nagla Nassar); financial law and practices between Islamic law and the current Egyptian legal system (Ziad BahaaEldin); the use of several legal sources in Egyptian courts regarding the rights of apostates (Ahmed Seif al-Islam Hamad); and the secular reconstruction of Islamic law by the Eyptian Supreme Constitutional Court in its decision regarding the veil in state-run schools (Kilian Bälz).

About the Editors

Baudouin Dupret is educated in Law, Arabic and Islamic Sciences at the Catholic University of Leuven, Belgium, and has a PhD in Political Sciences from the IEP (Institut d'Etudes Politiques), Paris. He is currently a researcher at CNRS researcher at CDEJ, Cairo.

Maurits Berger studied Dutch Law and Arabic Studies with a specialization in Islamic Law at the University of Utrecht, the Netherlands. He has practised as a lawyer and is currently a PhD student at the University of Amsterdam. Laila al-Zwaini studied Dutch Law and Arabic Studies at Leiden University, the Netherlands has a degree in Islamic and Middle Eastern from SOAS, London. She presently works as a PhD student at Leiden University.

Legal Pluralism in the Arab World edited by Baudouin Dupret, Maurits Berger, Laila al-Zwaini ISBN 90-411-1105-0 Hardback, 304 pages Kluwer Law International, February 1999 